\title{
PERUBAHAN SOSIAL BUDAYA DAN TINGKAT KESEJAHTERAAN MIGRAN BATAK DI SEKTOR INFORMAL DI KOTA BOGOR
}

\author{
The Changes of Social Culture and The Level of Migrant Welfare Batak Who Worked in The \\ Informal Sector in Bogor
}

\author{
Fuad Habibi Siregar*) dan Rilus A.Kinseng \\ Departemen Sains Komunikasi dan Pengembangan Masyarakat, Fakultas Ekologi Manusia, IPB \\ *Email: siregarfuad@yahoo.com
}

\begin{abstract}
The purpose of this research is to analyze the changes of social culture and the level of migrant welfare Batak who worked in the informal sector in the city of Bogor. This research provides a combination of qualitative and quantitative approaches. The qualitative approach is obtained from the results of the in-depth interviews. Quantitative survey method using approaches that take the 35 respondents. There is no society which does not suffer changes Migrant Batak is no exception. Changes that occur on the migrants include Batak culture and social change in the level of well-being. Social change include the interactions he does as well as relations with his family before and after becoming migrants. Culture change includes the values of religion, customs and mindset towards material and individualist attitudes. The welfare changes include income levels, access to medical services as well as housing conditions and ownership of the valuables owned by migrant Batak before and after become migrants in the informal sector.
\end{abstract}

Keywords: changes, social structures and cultural structures, the level of migrant welfare.

\begin{abstract}
ABSTRAK
Tujuan dari penelitian ini adalah untuk menganalisis perubahan sosial budaya dan tingkat kesejahteraan migran Batak yang bekerja di sektor informal di kota Bogor. Penelitian ini memberikan kombinasi pendekatan kualitatif dan kuantitatif. Pendekatan kualitatif diperoleh dari hasil wawancara mendalam. Metode survei kuantitatif menggunakan pendekatan yang mengambil 35 responden. Tidak ada masyarakat yang tidak menderita perubahan Migran Batak tidak terkecuali. Perubahan yang terjadi pada migran termasuk budaya Batak dan perubahan sosial di tingkat kesejahteraan. Perubahan sosial meliputi interaksi yang dilakukannya serta hubungan dengan keluarganya sebelum dan setelah menjadi migran. Perubahan budaya mencakup nilainilai agama, adat-istiadat dan pola pikir terhadap sikap material dan individualis. Perubahan kesejahteraan meliputi tingkat pendapatan, akses terhadap pelayanan kesehatan serta kondisi perumahan dan kepemilikan barang-barang berharga milik Batak migran sebelum dan sesudah menjadi migran di sektor informal.
\end{abstract}

Kata kunci: perubahan, struktur sosial dan struktur budaya, tingkat kesejahteraan migran.

\section{PENDAHULUAN}

\section{Latar Belakang}

Menurut Tjiptoherijanto (2000) dalam Safrida (2008), migrasi merupakan perpindahan orang dari daerah asal ke daerah tujuan. Keputusan migrasi didasarkan pada perbandingan untung rugi yang berkaitan dengan kedua daerah tersebut. Tujuan utama migrasi adalah meningkatkan taraf hidup migran dan keluarganya, sehingga umumnya mereka mencari pekerjaan yang dapat memberikan pendapatan dan status sosial yang lebih tinggi di daerah tujuan. Sejalan dengan definisi tersebut, Martin (2003) menyatakan migrasi adalah perpindahan penduduk dari satu daerah ke daerah lain, yang terjadi karena adanya perbedaan kondisi kedua daerah tersebut. Riwayat migrasi sudah setua riwayat manusia. Orang mungkin bermigrasi karena terpaksa, diatur atau tidak diatur, berkelompok atau secara perseorangan. Sebagai pendorong mungkin keadaan alam (termasuk bencana alam), keadaan politik, keadaan ekonomi atau kelangkaan berbagai fasilitas. Walaupun dalam keputusan bermigrasi berbagai faktor mempengaruhi, secara umum kiranya faktor ekonomi dianggap dominan. Singarimbun dalam Naim (1979) mengatakan faktor psikologi sosial jelas mengambil bagian pula karena tindakan ini menyangkut keputusan yang penting bagi seseorang atau keluarga yang bersangkutan. Bermigrasi sering merupakan keputusan yang begitu penting karena dapat merubah jalan hidup seseorang atau juga kelompok dan keturunan mereka secara fundamental.

Untuk memperoleh pekerjaan di daerah tujuan migrasi bukanlah pekerjaan yang mudah, hal ini disebabkan lapangan pekerjaan di daerah tujuan juga sudah memiliki tenaga kerja yang cukup dan seandainya jika membutuhkan tenaga kerja biasanya memiliki syarat-syarat yang harus 
dipenuhi oleh pencari kerja. Seringkali syarat-syarat yang diajukan oleh pemberi kerja tidak dapat dipenuhi karena keterbatasan keterampilan, pengetahuan, pendidikan serta pengalaman pencari kerja. Dari segi pendidikan biasanya migran ini sangat rendah. Proses pencarian pekerjaan ini ternyata tidak semudah yang dibayangkan oleh para migran karena terdapatnya kendala seperti jenis lowongan pekerjaan yang tidak sesuai dengan keterampilan dan tingkat pendidikan migran. Ketidakmampuan migran memperoleh pekerjaan seringkali mendorong para migran ini untuk bekerja di sektor informal. Hal ini disebabkan sektor informal tidak menuntut migran untuk mempunyai keterampilan dan pengetahuan lebih. Manning dan Effendi (1985) mengemukakan istilah sektor informal biasanya digunakan untuk menunjukkan sejumlah kegiatan ekonomi yang berskala kecil. Selanjutnya dikatakan pula bahwa sektor informal merupakan suatu manifestasi dari situasi pertumbuhan kesempatan kerja di negara-negara sedang berkembang.

Kota Bogor merupakan salah satu tujuan migrasi. Orangorang yang melakukan migrasi ke Kota Bogor terdiri dari beragam macam baik suku maupun budaya. Salah satu suku yang melakukan migrasi ke Kota Bogor adalah suku Batak. Castles (1967) dalam Naim (1979) memperkirakan bahwa tahun 1961 terdapat kira-kira 29.000 orang Batak berdiam di Jakarta, 40.000 sampai 50.000, berada di Jawa. Suku Batak yang bermigrasi ke Kota Bogor salah satunya untuk bekerja. Sektor informal merupakan salah satu sektor yang tidak luput dari orang-orang Batak ini. Banyak orang Batak yang bekerja di sektor informal di Kota Bogor

Ankie dalam Hatu (2011) berpendapat bahwa tidak ada masyarakat yang berhenti perkembangannya, karena setiap masyarakat mengalami perubahan yang terjadi secara lambat atau cepat. Perubahan dalam masyarakat pada dasarnya akan menyangkut hampir semua aspek atau segi masyarakat. Sesuai dengan pernyataan tersebut, hal ini juga terjadi pada migran Batak yang bekerja di sektor informal. Gillin dan Gillin dalam Marius (2006) mengatakan perubahan sosial sebagai suatu variasi dari cara-cara hidup yang telah diterima, yang disebabkan baik karena perubahan kondisi geografis, kebudayaan materiil, komposisi penduduk, ideologi, maupun karena adanya difusi maupun penemuan-penemuan baru dalam masyarakat tersebut.

Migran Batak yang bekerja di sektor informal seringkali mengalami perubahan dalam kehidupannya. Perubahan ini terjadi setelah ia melakukan migrasi. Banyak faktor yang menyebabkan perubahan ini baik dari segi perubahan tempat tinggal, interaksi dengan berbagai orang yang berbeda, dari segi pekerjaan dan seterusnya. Perubahan dalam kehidupan migran di sektor informal mencakup perubahan sosial budaya serta tingkat kesejahteraannya. Hal ini menjadi menarik untuk mengetahui sejauh mana sebenarnya perubahan yang dirasakan oleh migran Batak yang bekerja di sektor informal di Kota Bogor dan apakah perubahan itu memberikan dampak positif atau negatif dalam kehidupan mereka.

\section{Rumusan Masalah}

Kota Bogor sebagai wilayah perkotaan menjadi salah satu tujuan untuk bermigrasi. Orang-orang yang bermigrasi berasal dari suku dan budaya yang berbeda. Salah satu suku yang bermigrasi adalah orang-orang Batak. Untuk memenuhi kebutuhan hidupnya salah satu sektor pekerjaan yang dilakukan adalah sektor informal. Perbedaan wilayah asal dan tujuan migrasi seringkali memberikan dampak perubahan, selain itu faktor jenis pekerjaan juga mempengaruhi perubahan tersebut. Perubahan yang terjadi mencakup banyak hal. Bagaimana perubahan sosial budaya yang terjadi terhadap migran Batak di sektor informal?

Salah satu motif seseorang melakukan migrasi yaitu agar dapat memperbaiki kondisi kesejahteraan hidupnya. Pertanyaannya, bagaimana tingkat kesejahteraan migran Batak sebelum dan sesudah bekerja di sektor informal? Apakah terjadi perubahan tingkat kesejahteraan? Apakah perubahan ini memberikan dampak positif atau negatif bagi migran Batak yang bekerja di sektor informal di Kota Bogor.

\section{Tujuan Penelitian}

Penulisan Studi Pustaka dengan topik "Perubahan Sosial Budaya dan Tingkat Kesejahteraan Migran Batak Di Sektor Informal Di Kota Bogor" ini bertujuan untuk:

1. Menganalisis perubahan sosial budaya yang terjadi pada migran Batak di sektor informal di Kota Bogor.

2. Menganalisis perubahan tingkat kesejahteraan yang terjadi pada migran Batak di sektor informal di Kota Bogor.

\section{Kegunaan Penelitian}

Penelitian ini akan bermanfaat bagi beberapa pihak, yaitu:

\section{Akademisi}

Penelitian ini dapat menjadi bahan referensi dan rujukan untuk penelitian-penelitian selanjutnya. Dengan merujuk penelitian ini diharapkan nantinya peneliti selanjutnya dapat memperbaiki kelemahan-kelemahan dari penelitian ini.

\section{Pemerintah}

Hasil penelitian ini diharapkan dapat menjadi bahan pertimbangan bagi pemerintah dalam mengambil dan menyusun kebijakan yang berkaitan tentang migran, kebudayaan dan sektor informal.

\section{Masyarakat}

Dapat menjadi sumber informasi bagi masyarakat seputar tentang kehidupan dan budaya para migran di sektor informal sehingga dapat saling menghargai dan menghormati dalam perbedaan.

\section{PENDEKATAN TEORITIS}

\section{Tinjauan Pustaka}

\section{Perubahan Sosial Budaya}

Pudjiwati (1995) dalam Sahab (2002) menunjukkan perubahan sosial itu merupakan implikasi dari hubungan interaksi antara orang, organisasi atau komunitas yang menyangkut struktur sosial, pola nilai, norma dan peranan. Hal ini sejalan dengan Kingley Davis dalam Soekanto (1990) yang mengartikan perubahan sosial sebagai perubahan-perubahan yang terjadi dalam struktur dan fungsi masyarakat. Perubahanperubahan sosial adalah segala perubahan pada lembaga- 
lembaga sosial didalam suatu masyarakat, yang mempengaruhi sistem sosialnya, termasuk didalamnya nilai-nilai, sikap-sikap dan pola-pola perilaku diantara kelompok-kelompok dalam masyarakat (Soemardjan, 1981)

Menurut Soedjito dalam Sahab (2002), perubahan sosial sebagai fenomena sosial, merupakan suatu gambaran dinamika masyarakat yang mengalami alih nilai-nilai tradisional. Nilainilai tradisional yang selama ini dipegang teguh beralih ke nilainilai kapitalis. Nilai-nilai tradisional yang mengedepankan kebersamaan digantikan dengan nilai-nilai kapitalis yang lebih individualis. Pergeseran masyarakat tradisional menjadi masyarakat kapitalis digambarkan oleh Lauer (2001) sebagai fenomena penting dari struktur sosial, berhubungan dengan pola-pola perilaku dan interaksi sosial. Konsekuensinya perubahan itu berwujud norma-norma, nilai-nilai dan adaptasi budaya yang dilihat oleh Evers dalam Sahab (2002) sebagai akibat pengaruh luar terhadap sendi-sendi kehidupan internal.

Perubahan dalam masyarakat pada dasarnya akan menyangkut hampir semua aspek atau segi masyarakat. Perubahanperubahan itu dapat mengenai nilai-nilai, norma-norma, pola-pola perilaku, organisasi, susunan lembaga-lembaga kemasyarakatan, lapisan-lapisan dalam masyarakat, kekuasaan dan wewenang, interaksi sosial, dan sebagainya (Soekanto, 1990).

Berbicara tentang perubahan banyak sekali ahli yang membedakan antara perubahan sosial dan perubahan kebudayaan. Suparlan dalam Hatu (2011) misalnya membedakan perubahan sosial dan perubahan kebudayaan. Menurutnya perubahan sosial adalah perubahan dalam struktur sosial dan dalam pola-pola hubungan sosial antara lain mencakup sistem status, hubungan-hubungan dalam keluarga, sistem-sistem politik dan kekuasaan serta persebaran penduduk, sedangkan perubahan kebudayaan perubahan yang terjadi dalam sistem ide yang dimiliki bersama oleh para warga atau sejumlah warga masyarakat yang bersangkutan, yang antara lain mencakup aturanaturan atau norma-norma yang digunakan sebagai pegangan dalam kehidupan warga masyarakat yang meliputi nilainilai, teknologi, selera dan rasa keindahan atau kesenian dan bahasa. Namun pada dasarnya antara perubahan sosial dan budaya itu merupakan satu kesatuan. Perubahan sosial merupakan cakupan dari perubahan budaya. Hal ini sejalan dengan pendapat Pujiwati dalam Hatu (2011) yang mengatakan bahwa tidak ada masyarakat yang tidak mempunyai kebudayaan, sebaliknya pula tidak ada kebudayaan yang tidak terjelma dalam suatu masyarakat. Dengan demikian istilah yang lebih lengkap semestinya adalah "perubahan sosial budaya". Davis dalam Soekanto (1982) menyatakan bahwa perubahan sosial merupakan bagian dari perubahan budaya.

\section{Penyebab Terjadinya Perubahan Sosial}

Menurut Bettelheim dan Janowtz dalam Halim (2002) di antara faktor-faktor yang mendorong dapatlah disebutkan kontak dengan kebudayaan lain, sistem pendidikan yang maju, toleransi terhadap perilaku yang menyimpang, stratifikasi yang terbuka, penduduk yang heterogen, dan ketidakpuasan terhadap bidang-bidang kehidupan tertentu. Daya pendorong faktor-faktor tersebut dapat berkurang karena adanya faktor-faktor yang menghambat, seperti kurangnya atau tidak ada hubungan dengan masyarakat lain, perkembangan ilmu pengetahuan yang terlambat, sikap masyarakat yang terlalu tradisionalistis, adanya kepentingan-kepentingan yang telah tertanam dengan kuat sekali, rasa takut akan kegoyahan pada integrasi kebudayaan, prasangka terhadap hal-hal yang baru, hambatan-hambatan yang bersifat ideologis, dan mungkin juga adat istiadat yang melembaga dengan kuat Menurut Soekanto (2000), faktor-faktor yang menyebabkan terjadinya perubahan sosial dan kebudayaan antara lain, yaitu bertambahnya penduduk, penemuan baru (inovasi), konflik dalam masyarakat, revolusi dalam masyarakat, peperangan, bencana alam, dan pengaruh interaksi dengan kebudayaan lain. Sajogyo (1985) mengatakan bahwa faktor pendukung terjadinya perubahan sosial yaitu intensitas hubungan atau kontak dengan kebudayaan lain, tingkat kebudayaan yang maju, sikap terbuka dari masyarakat, dan sikap ingin berkembang dan maju dari masyarakat. Sebab-sebab terjadinya perubahan sosial-budaya antara lain dikarenakan adanya perubahan demografi (demographic change), pergerakan dan perubahan sosial (social movement and change), serta adanya penemuan-penemuan. Penemuan itu sendiri meliputi persebaran kebudayaan (diffusion), inovasi dan evolusi kebudayaan (Koentjaraningrat, 1986).

\section{Tingkat Kesejahteraan}

Menurut Undang-undang No 11 Tahun 2009, kesejahteraan sosial adalah kondisi terpenuhinya kebutuhan material, spiritual, dan sosial warga negara agar dapat hidup layak dan mampu mengembangkan diri, sehingga dapat melaksanakan fungsi sosialnya. Todaro dalam Parassa (2012) mengemukakan bahwa kesejahteraan masyarakat menengah ke bawah dapat direpresentasikan dari tingkat hidup masyarakat. Tingkat hidup masyarakat ditandai dengan terentaskannya dari kemiskinan, tingkat kesehatan yang lebih baik, perolehan tingkat pendidikan yang lebih tinggi, dan tingkat produktivitas masyarakat .Badan Pusat Statistik (2000) menerangkan bahwa guna melihat tingkat kesejahteraan rumah tangga suatu wilayah ada beberapa indikator yang dapat dijadikan ukuran, antara lain adalah :

\section{Tingkat pendapatan keluarga;}

2. Komposisi pengeluaran rumah tangga dengan membandingkan pengeluaran untuk pangan dengan non-pangan;

3. Tingkat pendidikan keluarga;

4. Tingkat kesehatan keluarga, dan;

5. Kondisi perumahan serta fasilitas yang dimiliki dalam rumah tangga.

\section{Migrasi}

Migrasi adalah suatu bentuk gerak penduduk geografis, spasial, atau teritorial antara unit-unit geografis yang melibatkan perubahan tempat tinggal yaitu tempat asal ke tempat tujuan. Orang yang melakukan migrasi disebut dengan migran, karena itu seseorang yang disebut sebagai migran ada kemungkinan telah melakukan migrasi lebih dari satu kali. Migrasi terjadi sepanjang waktu, sehingga jumlah migran atau migrasi sering dihitung untuk jangka waktu tertentu atau interval migrasi. Jika tidak menggunakan interval migrasi (misal 1 tahun, 5 tahun, 10 tahun, dan sebagainya), jumlah migran atau migrasi dihitung hanya dengan mempertimbangkan tempat lahir. Dalam hal ini, setiap orang yang ditemukan bertempat tinggal atau berdomisili di luar tempat kelahirannya disebut sebagai migran semasa hidup. Migran di suatu wilayah dapat pula diidentifikasi berdasarkan tempat tinggal terakhir dan 
tempat tinggal dalam periode tahun-tahun belakangan. Semua migran yang berbeda antara tempat tinggal terakhir dan tempat tinggal sekarang dikatakan sebagai migran total (total migran), sedangkan migran yang tempat tinggalnya dalam periode tahun-tahun belakangan (umpamanya dalam 5 tahun terakhir) berbeda dari tempat tinggal sekarang disebut dengan migran risen (recent migrant). Selain itu, di suatu wilayah mungkin juga terdapat migrasi yang disebut dengan migrasi kembali (return migrant), yaitu seseorang yang tempat tinggalnya sekarang tidak berbeda dengan tempat lahir, tetapi untuk jangka waktu tertentu pernah bertempat tinggal di luar tempat kelahirannya (Rusli, 2012). Mantra (1992) dalam Safrida (2008) menjelaskan bahwa motivasi utama orang melakukan perpindahan dari daerahnya (pedesaan) ke perkotaan adalah motif ekonomi.

\section{Migrasi Suku Batak}

Suku Batak terdiri atas lima subsuku, yaitu Batak Toba, Batak Angkola-Mandailing, Batak Simalungun, Batak Karo dan Batak Pakpak/Dairi. Kozok (1999:11) mengatakan bahwa definisi awal tentang Batak adalah sebutan bagi semua suku yang tidak atau belum memeluk agama Islam. Hal ini sudah mengalami perubahan, sekarang hanya suku Batak Toba saja yang menyebutnya sebagai Batak, sedangkan subsuku yang lain cenderung meninggalkan nama Batak tersebut. Namun menurut Kozok (1999:12) sesungguhnya kelima subetnis tersebut merupakan bagian dari Batak.

Menurut Kamus Besar Bahasa Indonesia tahun 2008, "Batak" mempunyai arti petualang, pengembara, sedang "membatak" berarti berpetualang, pergi mengembara. Naim (1979) dalam Sinaga (2012) mengatakan orang Batak sangat suka mengembara. Mobilitas yang tinggi dan semangat serta perasaan ingin tahu yang sangat besar menjadi salah satu faktor yang membuat suku ini tersebat di mana-mana di nusantara pun di luar negeri.

Provinsi Jawa Barat merupakan kota tujuan migran. Seperti data arus migrasi masuk ke Provinsi Jawa Barat pada tahun 2000 yang dilansir BPS, ada sebanyak 1.097.021 jiwa migran yang masuk ke Jawa Barat dalam kurun waktu 1995-2000. Dari total migran yang masuk tersebut, penduduk asal Sumatera Utara yang berdomisili di Jawa Barat berjumlah 43.890 orang (4 persen) dan itu menduduki peringkat kelima dari seluruh penduduk provinsi lain yang kini berdomisili di Jawa Barat (Sinaga, 2012).

\section{Sektor Informal}

Konsep sektor informal yang dikemukakan pertama kali oleh Hart (1991) dalam Amalia (2013) adalah konsep unit usaha dengan ciri-ciri padat karya, pengelolaan bersifat kekeluargaan, tingkat pendidikan formal yang rendah, mudah dimasuki oleh pandatang baru, sifat usaha berubah-ubah dan tidak stabil. Sumodiningrat (1990) mengemukakan bahwa sektor informal perkotaan dunia ketiga, umumnya menjadi tumpuan lapangan usaha dan kerja para migran desa kota. Para migran dari pedesaan ini pada umumnya berpendidikan sangat rendah dan tidak terampil, oleh karenanya mereka sulit bersaing untuk masuk ke sektor formal, sehingga hanya terserap oleh sektor informal. Namun demikian, sumbangan yang diberikan sektor ini dalam sistem ekonomi perkotaan cukup besar. Sektor ini cukup berperan penting, terutama dalam melayani konsumen lapisan bawah yang memiliki daya beli relatif rendah, yang tidak memungkinkannya untuk menjangkau sektor formal. Sektor informal sangat berarti bagi kelangsungan hidup masyarakat miskin di perkotaan.

\section{Kerangka Pemikiran}

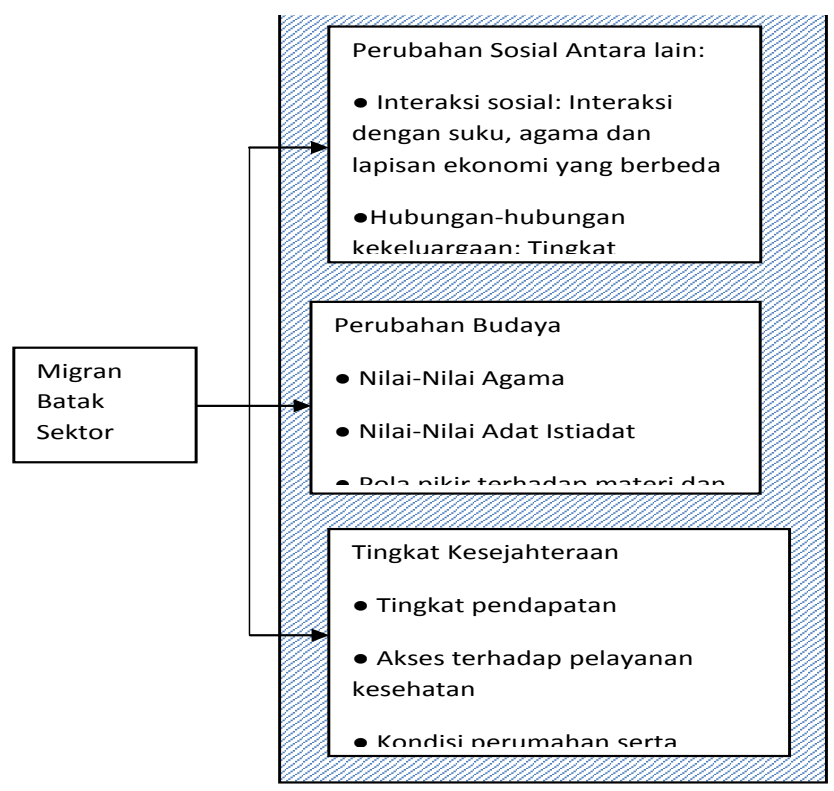

Keterangan:

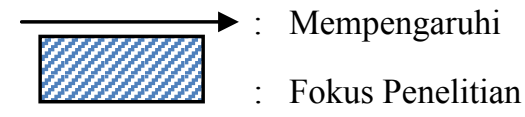

Gambar 1 Kerangka pemikiran

Kondisi lingkungan yang berbeda sedikit banyaknya berpengaruh terhadap kehidupan migran Batak di sektor informal. Pengaruh ini bisa berdampak positif dan negatif sejauh mana migran dapat menyesuaikan diri. Perubahan yang terjadi terhadap migran Batak di sektor informal mencakup perubahan sosial budaya dan tingkat kesejahteraan. Penelitian ini membatasi perubahan sosial budaya mencakup interaksi sosial, hubunganhubungan kekeluargaan, nilai-nilai agama, nilai-nilai adat istiadat, perubahan pola pikir terhadap materi dan sikap individualis, sedangkan perubahan tingkat kesejahteraan dilihat dari indikator tingkat pendapatan, tingkat kesehatan dan kondisi perumahan serta kepemilikan barang berharga

\section{PENDEKATAN LAPANG}

\section{Metode Penelitian}

Penelitian ini menggunakan pendekatan kualitatif dan kuantitatif. Penelitian kualitatif bersifat explanatory research dengan menggunakan teknik wawancara mendalam dan observasi langsung. Penelitian kuantitatif yang dilakukan merupakan metode penelitian survei. Pendekatan kuantitatif dilakukan melalui pengisian kuesioner.

\section{Lokasi dan Waktu Penelitian}

Penelitian ini akan dilaksanakan di Kota Bogor. Lokasi penelitian ditentukan secara purposive (sengaja). Alasan pemilihan lokasi penelitian adalah Kota Bogor merupakan 
salah satu daerah yang memiliki komunitas migran Batak yang bekerja di sektor informal yang tinggi. Kegiatan penelitian ini dilaksanakan dalam jangka waktu enam bulan yang terhitung mulai bulan Februari 2014 sampai dengan Juli 2014.

\section{Teknik Pengumpulan Data}

Jenis data berdasarkan sumbernya yang digunakan dalam penelitian ini adalah data primer dan sekunder. Perubahan yang terjadi diukur menurut pandangan responden secara subjektif. Populasi sasaran dalam penelitian ini adalah seluruh migran batak yang bekerja disektor informal Kota Bogor. Unit analisis dalam penelitian ini adalah individu migran batak yang bekerja disektor informal. Migran dalam hal ini adalah setiap orang yang ditemukan bertempat tinggal atau berdomisili di luar tempat kelahirannya atau disebut sebagai migran semasa hidup (Rusli, 2012). Penentuan responden dilakukan dengan pengambilan sampel "accidental sampling". Cara ini dilakukan karena jumlah orang Batak yang ada di Bogor tidak terdata secara statistik. Teknik Accidental sampling yaitu responden dipilih secara tidak sengaja.

\section{Teknik Pengolahan dan Analisis Data}

Data kualitatif diolah melalui tiga jalur analisis yaitu reduksi data, penyajian data dan penarikan kesimpulan. Data kualitatif diolah melalui instrumen kuesioner. Data hasil kuesioner kemudian diolah menggunakan microsoft excel 2014 dan SPSS for windows versi 20. Data yang diperoleh melalui kuesioner kemudian diolah dan dimasukan ke perangkat lunak microsoft excel 2014 sebelum dimasukan ke perangkat lunak SPSS for Windows versi 20 untuk mempermudah pengolahan data. Kemudian data yang didapatkan dianalisis secara statistik dengan menggunakan Analisis Uji Beda (T-Paired Sample). Analisis data dengan pengujian ini untuk menguji perbedaan kondisi aspek perubahan sosial budaya dan tingkat kesejahteraan responden sebelum dan sesudah menjadi migran di sektor informal di Kota Bogor. Pada uji beda ini digunakan total nilai dari semua indikator.

\section{GAMBARAN UMUM KOTA BOGOR DAN MIGRAN BATAK SEKTOR INFORMAL DI KOTA BOGOR}

\section{Gambaran Umum Kota Bogor}

Kota Bogor merupakan salah satu kota yang terletak di Propinsi Jawa Barat yang memiliki luas wilayah sekitar 11.850 hektar. Kota Bogor terletak $\pm 56 \mathrm{Km}$ selatan dari Ibu Kota Jakarta dan $\pm 130 \mathrm{Km}$ barat Kota Bandung, Ibu Kota Provinsi Jawa Barat. Secara administratif Kota Bogor melingkupi enam wilayah kecamatan, yaitu Kecamatan Bogor Timur, Kecamatan Bogor Utara, Kecamatan Bogor Tengah, Kecamatan Bogor Barat, Kecamatan Bogor Selatan dan Kecamatan Tanah Sareal.

Hasil Registrasi Penduduk tahun 2012 menunjukkan bahwa jumlah penduduk Kota Bogor sebanyak 1.004.831 jiwa yang terdiri dari 510.884 jiwa laki-laki dan 493.947 jiwa perempuan. Jumlah penduduk Kota Bogor dari tahun ke tahun mengalami pertumbuhan. Angka pertumbuhan penduduk ini, dipengaruhi oleh faktor alamiah (kelahiran dan kematian) dan faktor migrasi masuk dan keluar. Migrasi masuk salah satunya disebabkan karena faktor penarik Kota
Bogor. Kota Bogor sebagai jalur perlintasan antara Provinsi DKI Jakarta dan Provinsi Jawa Barat telah meletakkan Kota Bogor sebagai Kota Penyangga Jakarta.

\section{Gambaran Umum Migran Batak di Sektor Informal di Kota Bogor}

Suku Batak yang ada di Kota Bogor terdiri dari beberapa sub suku yaitu Batak Toba, Batak Angkola-Mandailing, Batak Simalungun, Batak Karo, dan Batak Pakpak/ Dairi. Selain itu, Migran Batak yang tinggal di Kota Bogor berasal dari daerah-daerah berbeda di Sumatera Utara serta memiliki agama-agama yang beragam.

Salah satu tujuan migran Batak di Kota Bogor adalah untuk bekerja atau mencari pekerjaan. Keterbatasan keterampilan dan kurangnya pendidikan menjadikan migran Batak banyak bekerja di sektor informal, hal ini disebabkan karena sektor ini dapat dengan mudah dimasuki. Pekerjaan migran Batak di sektor informal antara lain membuka warung sembako, membuka warung minuman, membuka warung makan, membuka bengkel, membuka tambal ban dan menyediakan jasa,

Jenis pekerjaan migran Batak di Kota Bogor mempengaruhi tempat tinggal mereka. Migran Batak yang membuka warung sembako di Kota Bogor umumnya tinggal di daerah-daerah pinggiran Kota Bogor. Hal ini disebabkan daerah pinggiran belum tersentuh mini market. Mini market merupakan salah satu saingan terbesar migran Batak yang membuka warung sembako. Migran Batak yang membuka bengkel biasanya terletak di dekat jalan raya yang ramai. Migran batak yang membuka warung minuman biasanya letaknya tersembunyi di sudut-sudut jalan. Hal ini dilakukan karena minuman yang dijual termasuk ke dalam jenis minuman keras, sedangkan yang menyediakan jasa umumnya terletak di dekat-dekat pusat-pusat pendidikan.

Jumlah migran Batak yang ada di Kota Bogor setiap tahun bertambah. Pertambahan jumlah ini tidak terdata secara statistik. Hal ini disebabkan banyak hal diantaranya mengurus tanda pengenal masih dirasakan sulit dilakukan karena seringkali prosesnya dipersulit oleh oknumoknum tertentu. Selain itu, migran Batak seringkali tidak mencantumkan marga mereka, padahal marga tersebut adalah identitas yang paling mudah dikenali.

Pertambahan jumlah migran Batak di Kota Bogor disebabkan dua faktor, yaitu faktor migran Batak sendiri dan dari faktor Kota Bogor sebagai tujuan migrasi. Faktor dari migran Batak sendiri bisa dilihat dari sistem kekerabatannya yang kuat terutama terkait dengan prinsip tolong menolong. Migran yang telah sukses akan berusaha membantu kehidupan saudaranya. Sistem tarik menarik saudara seringkali dilakukan oleh migran yang kehidupannya telah membaik. Selain itu, kecenderungan perubahan kehidupan ke arah yang lebih baik membuat para migran ini untuk menetap di Kota Bogor, dan tak jarang pula mereka menikah dan menghasilkan keturunan yang ikut menambah jumlah mereka.

Dari faktor Kota Bogor sebagai tujuan migrasi bisa dilihat dari perkembangan perekonomiannya yang selalu stabil dan cenderung meningkat. Hal ini menjanjikan untuk para migran. Disamping itu, berbagai fasilitas yang mendukung seperti fasilitas transportasi, pendidikan, kesehatan, air bersih, listrik maupun fasilitas peribadatan memudahkan 
mereka karena dapat diakses dengan mudah. Hal ini menjadi salah satu faktor pertambahan jumlah migran Batak di Kota Bogor. Selain itu, keramahan dan sikap terbuka yang baik dari masyarakat Kota Bogor membuat para migran ini nyaman untuk tinggal di Kota Bogor sehingga jumlahnya dari tahun ke tahun selalu bertambah.

\section{KARAKTERISTIK MIGRAN BATAK DI SEKTOR INFORMAL DI KOTA BOGOR}

\section{Umur}

Responden pada penelitian ini sebanyak 35 orang. Terdapat tiga tingkatan umur responden yaitu umur rendah $(\leq 20)$, umur sedang (21-30) dan umur tinggi $(\geq 31)$. Sebanyak 1 responden $(2.85 \%)$ masuk ke dalam kategori umur rendah yang berusia di bawah 20 tahun, sebanyak 17 responden $(48.5 \%)$ masuk kedalam kategori umur sedang yang berusia antara 21-30 tahun dan sebanyak 17 responden masuk kedalam kategori umur tinggi yaitu berusia diatas 31 tahun.

Tabel 1. Jumlah dan persentase responden berdasarkan tingkat usia

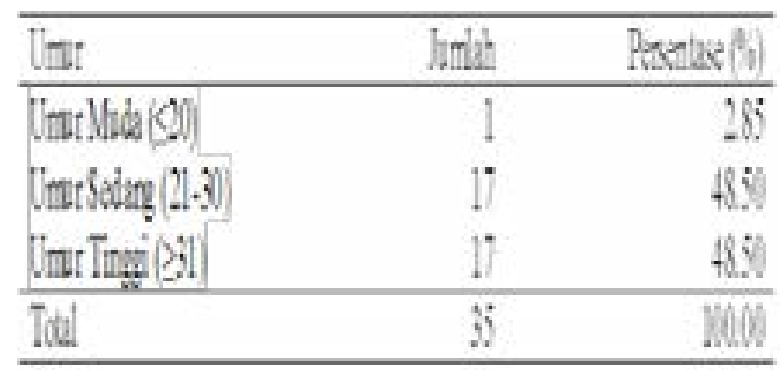

Tingkat Pendidikan

Migran yang bekerja di sektor informal di Kota Bogor mayoritas lulusan SMA. Hal ini bisa dilihat dalam tabel di bawah ini.

Tabel 2. Jumlah dan persentase responden berdasarkan tingkat pendidikan

\begin{tabular}{|c|c|c|}
\hline Patiden & 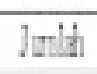 & Prontax (4) \\
\hline $8 D$ & 0 & \\
\hline$S M P$ & 4 & 11.40 \\
\hline SMA & 27 & 77.10 \\
\hline$D\}$ & ? & 571 \\
\hline$\$ 1$ & 2 & 571 \\
\hline Tod & 35 & 10000 \\
\hline
\end{tabular}

\section{Subsuku}

Suku Batak terdiri dari beberapa subsuku. Berdasarkan data penelitian yang ditemukan di lapang ada 24 orang $(68,5 \%)$ Mandailing, 10 orang $(28.5 \%)$ Toba dan 1 orang $(2.85 \%)$ berasal dari subsuku Simalungun.
Tabel 3. Jumlah dan persentase responden berdasarkan subsuku Batak

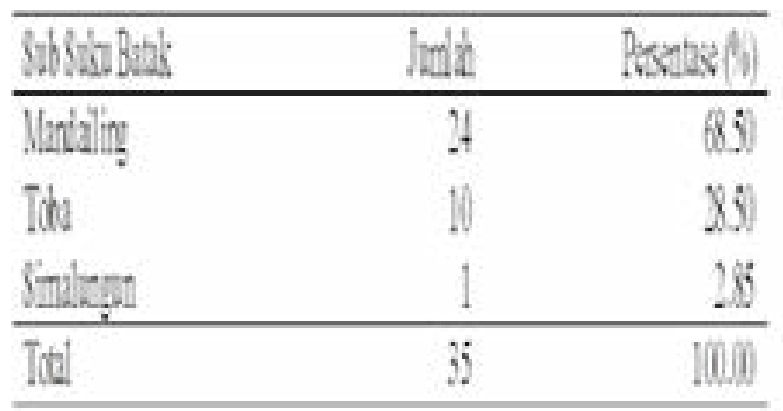

Berdasarkan data tabel diatas dapat disimpulkan dari 35 responden penelitian ternyata di dominasi oleh subsuku Batak Mandailing.

\section{Agama}

Migran Batak yang bekerja di sektor informal di Kota Bogor ternyata didominasi oleh migran yang beragama Islam.

Tabel 4. Jumlah dan persentase responden menurut agamanya

\begin{tabular}{lrr}
\hline Agama & Jumlah & Persentase $(\%)$ \\
\hline Islam & 26 & 74.20 \\
Protestan & 8 & 22.80 \\
Katolik & 1 & 2.85 \\
\hline Total & 35 & 100.00 \\
\hline
\end{tabular}

Berdasarkan data yang didapatkan di lapang, ternyata Agama yang dianut oleh responden memiliki keterkaitan dengan subsuku responden. Hal tersebut dapat dilihat pada tabel di bawah ini.

Tabel 5. Keterkaitan antara agama dan sub suku responden

\begin{tabular}{|c|c|c|c|c|c|c|c|c|}
\hline \multirow{3}{*}{ Agama } & \multicolumn{6}{|c|}{ Sub Suku } & \multirow{2}{*}{\multicolumn{2}{|c|}{ Total }} \\
\hline & \multicolumn{2}{|c|}{ Mandaling } & \multicolumn{2}{|c|}{ Toba } & \multicolumn{2}{|c|}{ Simalungun } & & \\
\hline & $\mathrm{N}$ & $\%$ & $\mathrm{~N}$ & $\%$ & $\mathrm{~N}$ & $\%$ & $\mathrm{~N}$ & $\%$ \\
\hline Islam & 23 & 88.4 & 3 & 11.5 & 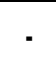 & . & 26 & 100.0 \\
\hline Protestan & & $\cdot$ & 7 & 87.5 & 1 & 12.5 & 8 & 100.0 \\
\hline Katolik & & . & 1 & 100.0 & . & & 1 & 100.0 \\
\hline Total & 23 & . & 11 & & 1 & & 35 & \\
\hline
\end{tabular}

Responden yang beragama Islam memiliki kecenderungan berasal dari subsuku Mandailing, responden yang beragama Protestan dan Katolik berasal dari subsuku toba dan simalungun. 


\section{Daerah Asal}

(62.8\%) migran berasal dari kawasan Kabupaten Madina yaitu kecamatan Panyabungan dan Kotanopan. Sebanyak 4 responden $(11.4 \%)$ berasal dari kawasan Padangsidimpuan, sebanyak 3 responden $(8.57 \%)$ masing-masing berasal dari kawasan Porsea dan Samosir. Sisanya berasal dari Medan, Pematangsiantar dan Tebing Tinggi.

Tabel 6. Daerah asal responden di Kota Bogor

\begin{tabular}{lrr}
\hline Daerah Asal & Jumlah & Persentase $(\%)$ \\
\hline Porsea & 3 & 8.57 \\
Panvabungan & 15 & 42.80 \\
Samosir & 3 & 8.57 \\
Medan & 1 & 2.85 \\
Kotanopan & 7 & 20.00 \\
Padangsidimpuan & 4 & 11.40 \\
Pematangsiantar & 1 & 2.85 \\
Tebing Tingoi & 1 & 2.85 \\
\hline Total & 35 & 100.00 \\
\hline
\end{tabular}

Daerah asal responden memiliki keterkaitan dengan agama yang dianut oleh responden. Hal ini bisa dilihat pada tabel di bawah ini.

Tabel 7. Keterkaitan antara daerah asal dan agama responden

\begin{tabular}{|c|c|c|c|c|c|c|c|c|}
\hline \multirow{3}{*}{ Daerah Asal } & \multicolumn{6}{|c|}{ Agama } & \multirow{2}{*}{\multicolumn{2}{|c|}{ Total }} \\
\hline & \multicolumn{2}{|c|}{ Islam } & \multicolumn{2}{|c|}{ Protestan } & \multicolumn{2}{|c|}{ Katolik } & & \\
\hline & $\mathrm{N}$ & $\%$ & $\mathrm{~N}$ & $\%$ & $\mathrm{~N}$ & $\%$ & N & $\%$ \\
\hline Porsea & . & . & 3 & 100 & . & . & 3 & 100 \\
\hline Panyabungan & 15 & 100 & - & . & . & . & 15 & 100 \\
\hline Samosii & $\cdot$ & . & 3 & 100 & . & . & 3 & 100 \\
\hline Medan & . & . & 1 & 100 & . & . & 1 & 100 \\
\hline Kotanopan & 7 & 100 & - & . & - & . & 7 & 100 \\
\hline Padangsidempuan & 4 & 100 & - & . & . & . & 4 & 100 \\
\hline Pematangsiantar & $\cdot$ & . & 1 & 100 & . & . & 1 & 100 \\
\hline Tebing Tingoi & - & . & $\cdot$ & . & 1 & 100 & 1 & 100 \\
\hline Total & 26 & ${ }^{\circ}$ & 8 & . & 1 & ${ }^{\circ}$ & 35 & . \\
\hline
\end{tabular}

Tabel menunjukkan responden yang berasal dari daerah Panyabungan, Kotanopan, dan Padangsidempuan beragama Islam. Responden yang berasal dari Porsea, Samosir, Medan, Pematangsiantar beragama Protestan dan respoden yang berasal dari Tebing Tinggi beragama Katolik.

\section{Lama Tinggal}

Lama tinggal menunjukkan berapa lama waktu yang telah dijalani oleh migran Batak untuk bekerja di kota tujuan migrasi yaitu Bogor.

Tabel 8. Jumlah dan persentase responden berdasarkan lama tinggal

\begin{tabular}{|c|c|c|}
\hline Lama Tingald & Jumala & 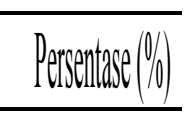 \\
\hline 〈SThamu & 1 & WII \\
\hline 5:DTdum & 17 & \\
\hline$>$ ONd dim & 11 & \\
\hline Trodal & 35 & \\
\hline
\end{tabular}

Lama tinggal di Kota Bogor akan mempengaruhi status tempat tinggal migran Batak yang bekerja di sektor informal. Hal tersebut dapat dilihat pada tabel.

Tabel 9. Keterkaitan antara lama tinggal di Bogor dan status tempat tinggal.

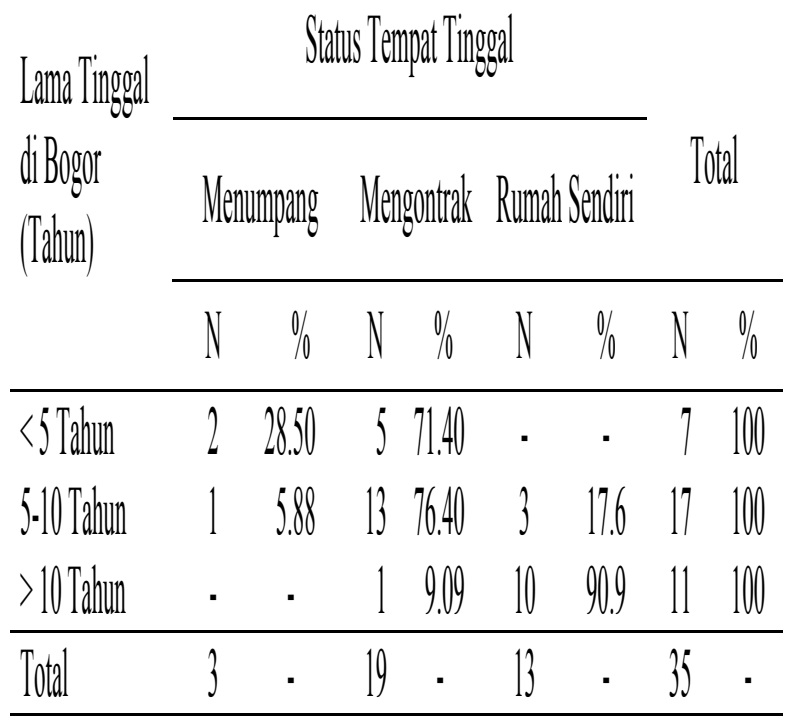

Tabel menunjukkan semakin lama tinggal di Kota Bogor kehidupan migran Batak mengalami perubahan, hal ini 
terlihat dari status tempat tinggal mereka dari menumpang, mengontrak dan memiliki rumah sendiri.

\section{Jenis Pekerjaan Sektor Informal}

Jenis pekerjaan sektor informal adalah jenis pekerjaan yang dijalankan oleh migran di sektor informal di Kota Bogor ketika penelitian berlangsung.

Tabel 10. Jumlah dan persentase responden berdasarkan jenis pekerjaannya

\begin{tabular}{|c|c|c|}
\hline Jenis pekergan informal & Jumlah & Persentiase (Po) \\
\hline WarnugSSembato & 26 & 7420 \\
\hline Warngyglakan & 1 & 2.85 \\
\hline Warnyy Yirumanan & 3 & 8.57 \\
\hline Tambal Ban & 3 & 8.57 \\
\hline Agen Konn dan Magalah & 1 & 2.85 \\
\hline Laundry & 1 & 285 \\
\hline Total & 35 & 100.00 \\
\hline
\end{tabular}

Dari tabel di atas dapat ditarik kesimpulan bahwa jenis pekerjaan membuka warung sembako merupakan jenis pekerjaan sektor informal yang diminati oleh migran Batak karena sangat menjanjikan. Berdasarkan data yang diperoleh di lapang, subsuku migran Batak memiliki keterkaitan dengan jenis pekerjaan informal yang dilakukan oleh migran Batak. Hal tersebut dapat dilihat pada tabel.

Tabel 11. Keterkaitan antara jenis pekerjaan sektor informal dan subsuku responden

\begin{tabular}{|c|c|c|c|c|c|c|c|c|}
\hline \multirow{3}{*}{$\begin{array}{l}\text { Jenis Pekerjaan } \\
\text { Sektor Informal }\end{array}$} & \multicolumn{6}{|c|}{ Sub Suku Batak } & \multirow{2}{*}{\multicolumn{2}{|c|}{ Total }} \\
\hline & \multicolumn{2}{|c|}{ Mandailing } & \multicolumn{2}{|c|}{ Toba } & \multicolumn{2}{|c|}{ Simalungun } & & \\
\hline & $\mathrm{N}$ & $\%$ & $\mathrm{~N}$ & $\%$ & $\mathrm{~N}$ & $\%$ & $\mathrm{~N}$ & $\%$ \\
\hline Warung Sembako & 23 & 88.4 & 3 & 11.5 & . & 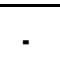 & 26 & 100 \\
\hline Warung Makan & 1 & 100.0 & $\cdot$ & - & . & . & 1 & 100 \\
\hline Warung Minuman & - & - & 3 & 100.0 & . & . & 3 & 100 \\
\hline Tambal Ban & . & . & 3 & 100.0 & . & . & 3 & 100 \\
\hline $\begin{array}{l}\text { Agen Koran dan } \\
\text { Majalah }\end{array}$ & - & . & 1 & 100.0 & . & - & & 100 \\
\hline Laundry & - & . & $\cdot$ & 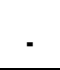 & 1 & 100 & 1 & 100 \\
\hline Total & 24 & . & 10 & - & 1 & & 35 & \\
\hline
\end{tabular}

\section{Alamat Tinggal di Kota Bogor}

Melalui tabel di bawah ini dijelaskan persebaran alamat tinggal migran Batak di sektor informal.

Tabel 12. Alamat tinggal responden di Kota Bogor

\begin{tabular}{lrr}
\hline Alamat Tinggal di Kota Bogor & Jumlah & Persentase $(\%)$ \\
\hline Kelurahan Margajaya Bogor Barat & 4 & 11.40 \\
Kelurahan Tegallega Bogor Tengah & 3 & 8.57 \\
Kelurahan Babakan Bogor Tengah & 5 & 14.20 \\
Kelurahan Bantariati Bogor Utara & 3 & 8.57 \\
Kelurahan Tegalgundil Bogor Utara & 6 & 17.10 \\
Kelurahan Katulampa Bogor Timur & 2 & 5.71 \\
Kelurahan Sindangorasa Bogor Timur & 1 & 2.85 \\
Kelurahan Kebonpedes Kecamatan Tanah sareal. & 3 & 8.57 \\
Kelurahan Tanah Baru Bogor Utara & 2 & 5.71 \\
Kelurahan Cipaku Bogor Selatan & 4 & 11.40 \\
Kelurahan Baranangsiang Bogor Timur & 2 & 5.71 \\
\hline \multicolumn{1}{c}{ Total } & 35 & 100.00 \\
\hline
\end{tabular}

\section{PERUBAHAN SOSIAL MIGRAN BATAK DI SEKTOR INFORMAL DI KOTA BOGOR}

Peneliti dengan menggunakan uji statistik T-test Paired atau uji beda yang berhubungan maka digunakan perangkat lunak SPSS dimana variable pengaruhnya adalah migrasi dan variabel terpengaruhnya adalah perubahan sosial. Kemudian melalui T-test Paired akan dilihat seberapa besar pengaruh migrasi terhadap perubahan sosial (sebelum dan sesudah melakukan migrasi) melalui nilai total yang didapatkan dari kuesioner mengenai perubahan sosial.

Tabel 13. Paired samples statistics perubahan sosial

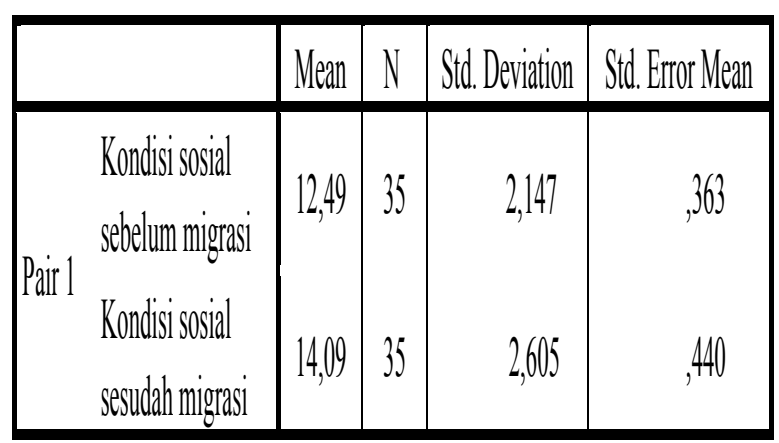

Hasil olah data statistik menunjukkan bahwa rata-rata (mean) kondisi sosial sebelum dan sesudah mengalami peningkatan positif dari 12,49 menjadi 14,09 dengan jumlah sampel $(\mathrm{N})=35$. 
Tabel 14. Paired samples test perubahan sosial

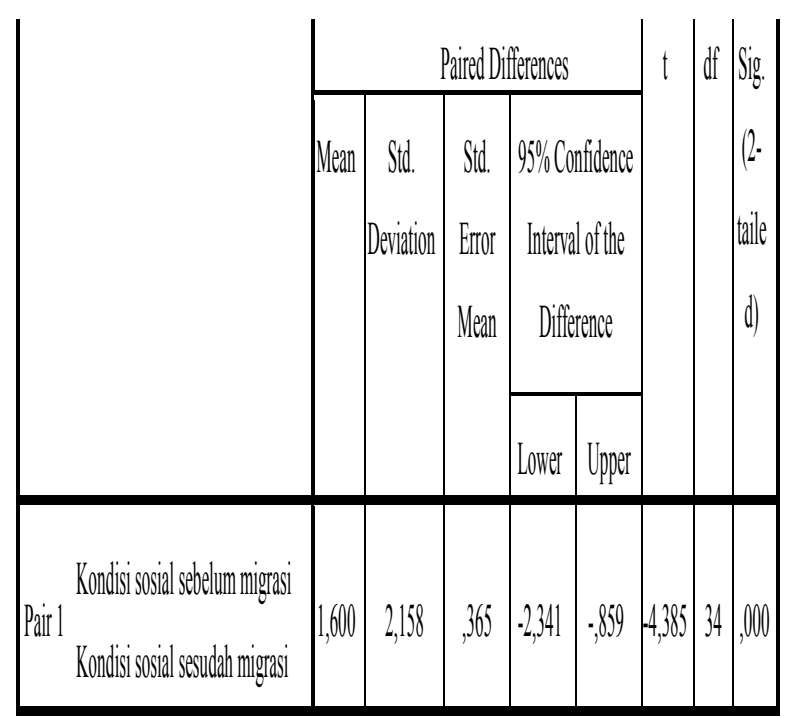

Berdasarkan aturan, jika sig $>0,05$ maka tidak ada hubungan antara sebelum dan sesudah migrasi dengan perubahan sosial migran Batak di sektor informal. Sebaliknya jika sig $<0,05$ maka ada hubungan antara sebelum dan sesudah menjadi migrasi dengan perubahan sosial migran Batak di sektor informal. Berdasarkan uji statistik di atas didapatkan nilai sig 0,000 yang berarti adanya hubungan antara sebelum dan sesudah migrasi dengan perubahan sosial migran Batak di sektor informal. Sig 0,000 ini juga menandakan bahwa adanya perbedaan kondisi sosial sebelum dan sesudah migrasi pada taraf kepercayaan 95 persen.

Dalam penelitian ini, perubahan sosial yang ingin diteliti adalah interaksi sosial dan hubungan-hubungan kekeluargaan. Interaksi sosial meliputi interaksi antara suku yang berbeda, interaksi antara agama yang berbeda dan interaksi antara lapisan ekonomi yang berbeda. Hubungan-hubungan kekeluargaan dilihat dari kedekatan dan kebersamaa dengan keluarga. Berikut akan dijelaskan setiap variabel perubahan sosial tersebut.

\section{Perubahan Interaksi Sosial}

\section{Perubahan Interaksi antara Suku yang Berbeda}

Masyarakat yang tinggal di wilayah asal migran Batak di sektor informal Kota Bogor adalah suku Batak. Sebagai daerah yang mayoritas berasal dari suku Batak sudah tentu dalam segi interaksi dilakukan dengan sesama orang Batak. Kalaupun ada interaksi dengan selain orang Batak jumlahnya tidak banyak. Interaksi yang dilakukan beragam sesuai dengan kebutuhannya masing-masing.

Di Kota Bogor interaksi dilakukan tidak dengan sesama Batak lagi. Interaksi antara suku yang berbeda menjadi hal yang biasa dilakukan. Interaksi banyak dilakukan dengan suku Sunda sebagai masyarakat asli Kota Bogor. Selain dengan suku Sunda interaksi juga dilakukan dengan suku-suku pendatang seperti suku Jawa, Betawi dan lain sebagainya. Kondisi Kota Bogor yang beragam suku budayanya mempengaruhi cara-cara interaksi yang dilakukan migran Batak ini. Di daerah asal interaksi dilakukan sesuai aturan dan norma yang ada di dalam suku Batak. Interaksi yang dilakukan lebih terbuka dan langsung. Berbeda interaksi yang dilakukan di daerah asal dan di Kota Bogor. Interaksi yang dilakukan di Kota Bogor cenderung mempertimbangkan nilai-nilai budaya lawan interaksinya dan cenderung kaku. Hal ini dilakukan untuk menjaga hubungan tetap baik dan harmonis serta untuk menghindari perselisihan.

Di Kota Bogor migran Batak tetap menjaga hubungan dengan sesama orang-orang Batak. Salah satu sarana untuk tetap menjalin hubungan tersebut dapat dilakukan melalui organisasi. Organisasi ini dapat didasari atas satu marga, satu subsuku, maupun satu agama. Fungsi dari organisasi ini diantaranya sebagai sarana untuk menjalin hubungan yang baik dengan sesama suku di tempat migrasi. Selain itu, organisasi ini juga dapat menjadi sarana tempat saling tolong-menolong.

Acara-acara organisasi yang rutin dilakukan adalah arisan dan acara keagamaan. Melalui arisan mereka bisa menabung dan menambah modal. Arisan dirasakan tidak memberatkan bagi migran karena iurannya tidak terlalu besar. Acara keagamaan banyak sekali fungsinya salah satunya memperkuat keimanan kepada Tuhan.

Organisasi berdasarkan marga adalah organisasi yang paling banyak diikuti oleh migran Batak. Hal ini disebabkan karena di dalam organisasi marga, migran menemukan adat budayanya secara langsung. Mereka juga merasakan melalui organisasi mereka seakan-akan berada di wilayah sendiri walaupun mereka berada di wilayah lain.

Dengan masuk organisasi mereka juga dapat menambah kenalan dan relasi di daerah migran. Hal ini cukup membantu para migran untuk dapat beradaftasi dan bertahan di Kota Bogor. Perkumpulan dibentuk untuk melestarikan adat budaya asal dan tempat bersilaturahmi dengan sesama Batak di daerah migrasi.

\section{Perubahan Interaksi antara Agama yang Berbeda}

Masyarakat Bogor mayoritas beragama Islam dan sangat menjunjung tinggi nilai-nilai agamanya. Masyarakat Kota Bogor juga terkenal sangat toleran dalam beragama. Hal ini dapat dilihat dari jarangnya terjadi perselisihan antar agama di Kota Bogor serta jumlah agama yang beragam di Kota Bogor.

Subsuku Batak yang beragama Islam dalam interaksinya di Kota Bogor sudah tentu berinteraksi dengan mayoritas yang beragama Islam, namun tidak menutup kemungkinan mereka juga berinteraksi dengan yang berbeda agama mengingat Kota Bogor sebagai wilayah perkotaan yang majemuk. Di samping itu faktor pekerjaan di sektor informal juga berpengaruh. Pekerjaan menuntut mereka untuk berinteraksi dengan agama yang berbeda. Subsuku Batak yang beragama non Islam berinteraksi dengan mayoritas beragama Islam. Umumnya interaksi dengan agama yang sama sering dilakukan pada kumpul acaraacara keagamaan seperti acara ibadah bersama atau pada acara-acara organisasi seagama yang diikuti.

\section{Perubahan Interaksi antara Lapisan Ekonomi yang Berbeda}

Lapisan ekonomi di daerah asal migran Batak dapat dikatakan beragam, namun jumlahnya masih terdiri 
dari lapisan ekonomi yang sama yaitu lapisan ekonomi menengah ke bawah, sedangkan lapisan ekonomi atas jumlahnya sedikit. Interaksi dengan lapisan ekonomi atas hanya dilakukan seperlunya saja. Hal ini disebabkan terdapat pandangan bahwa lapisan ekonomi atas lebih tinggi derajatnya dibanding dengan lapisan ekonomi menengah ke bawah, sehingga mereka sungkan untuk berinteraksi.

Setelah menjadi migran di Kota Bogor dan bekerja di sektor informal, interaksi mereka dilakukan dengan semua lapisan ekonomi. Mereka melakukan interaksi dengan lapisan bawah, menengah dan atas. Bekerja di sektor informal mewajibkan mereka untuk berinteraksi dan membangun hubungan baik dengan berbagai lapisan ekonomi untuk dapat bertahan hidup. Interaksi dengan lapisan ekonomi atas sering dilakukan dalam pekerjaan mereka. Interaksi yang terjadi sebatas hubungan antara penjual dan pembeli. Pandangan awal mereka tentang lapisan ekonomi atas sedikit demi sedikit berubah.

\section{Perubahan Hubungan-Hubungan Kekeluargaan}

\section{Perubahan pada Kedekatan dan Kebersamaan Keluarga}

Jarak yang jauh mempengaruhi kedekatan dan kebersamaan migran dengan keluarga. Intensitas bertemu dan berkomunikasi dengan keluarga berkurang tidak seperti dahulu saat mereka bersama-sama. Hal ini berakibat kepada kedekatan dan kebersamaan mereka menjadi terganggu dan cenderung merenggang. Hal ini semakin terlihat ketika terjadi suatu masalah dalam hubungan-hubungan keluarga mereka. Masalah tidak terselesaikan dengan baik dan cenderung mengambang.

Kedekatan dan kebersamaan migran dan keluarganya yang merenggang seringkali menimbulkan rasa tidak saling percaya serta sikap tidak terbuka antara migran dan keluarganya. Posisi sebagai migran juga menghadirkan banyak anggapan miring dari keluarganya. Untuk menjaga hubungan baik dengan keluarga di kampung, umumnya migran yang bekerja di sektor informal di Kota Bogor bertemu keluarganya minimal sekali dalam setahun. Migran yang beragama Islam pulang bertemu keluarga di kampungnya saat hari Raya Idul Fitri, sedangkan migran yang beragama Protestan dan Katolik pada saat hari Raya Natal.

Perubahan kedekatan dan kebersamaan dengan keluarga antara migran yang sudah berkeluarga dan yang belum berkeluarga berbeda. Migran yang belum berkeluarga memiliki intensitas pulang untuk bertemu dengan keluarga lebih banyak, karena mereka tidak terikat dengan apapun serta memiliki waktu yang lebih banyak. Kepulangan mereka ke kampung halaman yang sering dilakukan juga dipengaruhi oleh kondisi keuangan. Hal ini disebabkan penghasilan yang diperoleh dari pekerjaan mereka hanya di peruntukkan untuk diri mereka sendiri. Migran yang sudah berkeluarga lebih jarang untuk pulang ke kampungnya karena ia sudah memiliki kehidupan dengan keluarganya. Selain itu, faktor ekonomi juga mempengaruhi karena biaya untuk pulang ke kampung mahal.

\section{PERUBAHAN BUDAYA MIGRAN BATAK DI SEKTOR INFORMAL DI KOTA BOGOR}

Peneliti dengan menggunakan uji statistik t-test Paired atau uji beda yang berhubungan maka digunakan perangkat lunak SPSS dimana variable pengaruhnya adalah migrasi dan variabel terpengaruhnya adalah perubahan budaya. Kemudian melalui T-test Paired akan dilihat seberapa besar pengaruh migrasi terhadap perubahan budaya (sebelum dan sesudah melakukan migrasi) melalui nilai total yang didapatkan dari kuesioner mengenai perubahan budaya.

Tabel 15. Paired samples statistics perubahan budaya

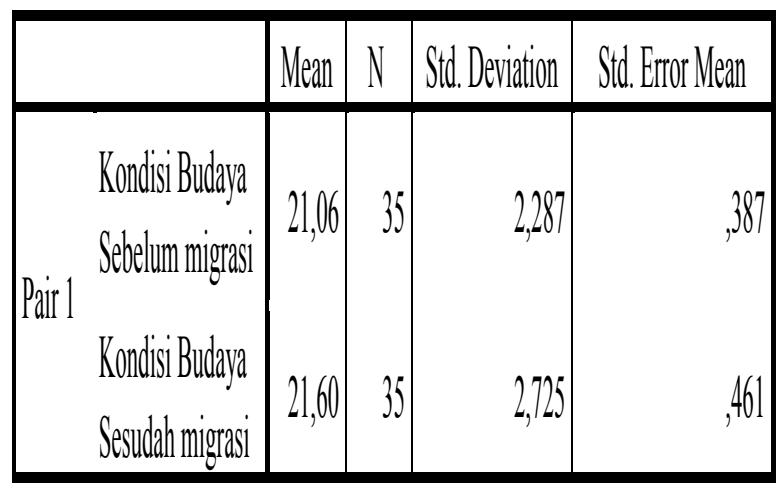

Hasil olah data statistik menunjukkan bahwa rata-rata (mean) kondisi budaya sebelum dan sesudah mengalami peningkatan yang sangat kecil dari 21,06 menjadi 21,60 dengan jumlah sampel $(\mathrm{N})=35$.

Berdasarkan aturan, jika sig $>0,05$ maka tidak ada hubungan antara sebelum dan sesudah migrasi dengan perubahan budaya migran Batak di sektor informal. Sebaliknya jika sig $<0,05$ maka ada hubungan antara sebelum dan sesudah migrasi dengan perubahan budaya migran Batak di sektor informal. Berdasarkan uji statistik di atas ini didapatkan nilai sig 0,328 yang berarti tidak adanya hubungan antara sebelum dan sesudah migrasi dengan perubahan budaya migran Batak di sektor informal. Sig 0,328 ini juga menandakan bahwa tidak adanya perbedaan kondisi budaya sebelum dan sesudah migran pada taraf kepercayaan 95 persen.

\section{Tabel 16. Paired Samples Test Perubahan Budaya}

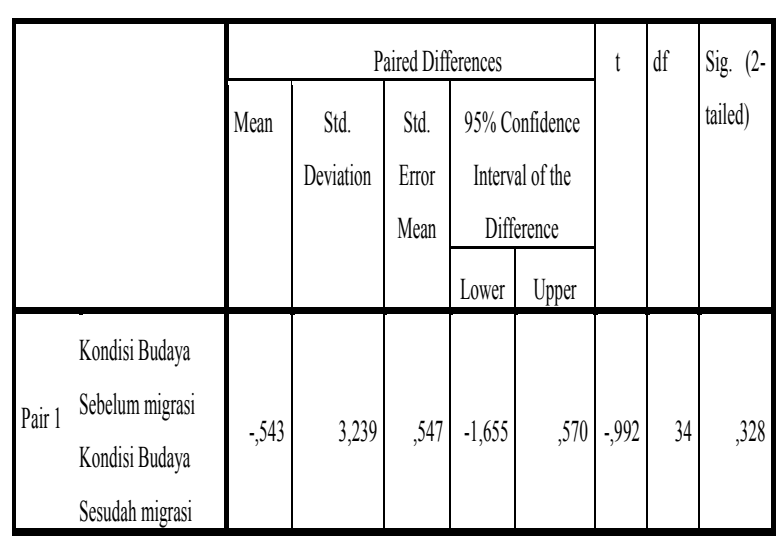

Migran Batak yang tidak mengalami perubahan budaya disebabkan antara lain:

1. Migran Batak sejak kecil sudah diajarkan nilai-nilai 
budaya dalam kehidupannya sehari-hari.

2. Migran Batak yang ada di Kota Bogor memiliki organisasi-organisasi. Organisasi ini memiliki peran kontrol terhadap perilaku.

3. Migran Batak tetap melestarikan budayanya melalui hubungan interaksinya dengan sesama suku Batak.

Dalam penelitian ini perubahan budaya yang akan diteliti mencakup nilai-nilai agama, nilai-nilai adat istiadat, serta pola pikir yang meliputi perubahan pola pikir terhadap materi dan perubahan pola pikir terhadap sikap individualis. Berikut akan diuraikan setiap variabel perubahan budaya tersebut.

\section{Perubahan Nilai-Nilai Agama}

Secara keseluruhan tidak ditemukan perubahan nilai-nilai agama migran Batak yang bekerja di sektor informal di Kota Bogor. Namun dari beberapa responden yang diwawancarai secara mendalam ternyata ada beberapa responden yang mengalami perubahan nilai-nilai agama. Berikut akan dijelaskan beberapa migran yang mengalami perubahan nilai-nilai agama tersebut.

Nilai-nilai agama sangat dijunjung tinggi oleh orang Batak, karena sejak kecil orang Batak sudah diajarkan agama oleh orangtuanya. Dalam perubahan nilai-nilai agama tidak ada indikator yang pasti. Perubahan nilai-nilai agama ini didasarkan penilaian pribadi migran. Untuk migran yang beragama Islam, penilaian mereka didasarkan pada kewajiban pelaksanaan sholat dan membaca kitab suci Al-quran. Untuk migran yang beragama Protestan dan Katolik, penilaian mereka didasarkan pada kewajiban pergi ke gereja.

Perubahan nilai-nilai agama migran Batak yang bekerja di sektor informal di Kota Bogor ada ke arah yang lebih baik dan ada juga sebaliknya serta ada juga yang tidak berubah. Biasanya migran Batak yang belum menikah mengalami perubahan nilai-nilai agama ke arah yang kurang baik, hal ini disebabkan karena sudah tidak bersama dengan keluarga sehingga tidak ada yang mengingatkan masalah nilai agama lagi. Mereka cenderung bebas dan kurang dikontrol. Keluarga sebagai peran kontrol sudah tidak ada lagi.

Migran Batak yang sudah menikah perubahannya cenderung ke arah yang lebih baik. Hal ini disebabkan sudah dewasa dan matangnya pola pemikiran mereka. Pola pemikiran mereka cenderung memandang ke depan. Setiap tindakan dan perbuatan mereka selalu dilakukan secara hati-hati. Setelah menikah mereka memposisikan diri sebagai calon orang tua. Sebagai orang tua yang kelak menjadi panutan anak-anaknya mereka harus mencontohkan hal-hal yang baik. Oleh karena itu mereka memulai dari dirinya sendiri. dengan meningkatkan nilai-nilai keagamaan yang dimiliki.

Migran Batak yang nilai-nilai agamanya tidak berubah biasanya sudah memiliki bekal agama yang kuat serta telah mengakar di dalam kepribadian dan dirinya.

\section{Perubahan Nilai-Nilai Adat Istiadat}

Suku Batak adalah salah satu suku yang sangat taat terhadap adat istiadat. Adat adalah sesuatu yang harus terus dipegang teguh. Tidak ada perubahan nilai-nilai adat istiadat yang berarti bagi migran Batak yang bekerja disektor informal Kota Bogor. Namun kondisi sebagai migran membuat beberapa nilai-nilai adat tidak dapat diterapkan. Bukan karena mereka meninggalkan nilai-nilai adat istiadat mereka, tetapi kondisi dan keadaan yang membuat mereka tidak dapat menerapkan nilai-nilai adat tersebut. Sebagai seorang migran yang ada di kampung orang sudah tentu kita saling menghargai. Tidak berkumpulnya migran dalam sebuah wilayah tempat tinggal membuat mereka kesulitan untuk melaksanakan adat istiadat mereka serta ada beberapa migran yang menikah dengan orang yang berbeda suku membuat pernikahan secara adat tidak memungkinkan dilaksanakan, seperti contoh dalam upacara pernikahan. Seorang migran Batak yang menjalankan pernikahannya terkadang tidak memakai adat istiadat suku Batak karena mereka berada di wilayah suku Sunda yang tidak mengerti mengenai adat suku Batak, sehingga mereka cenderung melaksanakan pernikahan secara modern tidak memakai adat istiadat. Pernikahan secara modern dianggap bisa diterima oleh semua suku secara terbuka.

\section{Perubahan Pola Pikir}

\section{Perubahan Pola Pikir Terhadap Materi}

Hampir seluruh migran Batak sekarang mulai berpikiran materialistis. Hal ini terlihat dari perilaku dan tindakan mereka dalam kehidupan sehari-hari. Migran Batak sekarang jarang mau melakukan sesuatu yang tidak memiliki keuntungan finansial. Selalu ada hitung-hitungan untung dan rugi dalam kehidupan mereka sekarang. Hal ini jauh berbeda ketika mereka berada di daerah asal. Materi bukanlah segalanya dan segalanya tidak dapat dibeli dengan materi. Perubahan pola pikir ini disebabkan banyak hal diantaranya perubahan kondisi di mana mereka berada sekarang. Di daerah, materi bukanlah penentu segalanya. Kebutuhan mereka juga terbatas. Tidak ada kebutuhan lain yang dibutuhkan mereka. Dalam pikiran mereka asalkan dapat bertahan hidup cukup makan semuanya sudah selesai. Berbeda dengan wilayah tempat tinggal mereka sekarang. Sebagai wilayah perkotaan segala sesuatu membutuhkan uang. Kondisi ini perlahan-lahan merubah pola pikir migran ke arah yang materialistis.

Sebagai wilayah perkotaan di mana-mana setiap orang berlomba-lomba mencari dan mengumpulkan uang sebanyak-banyaknya, hal ini mempengaruhi migran Batak dalam hidupnya, orientasi materi menjadi tujuan hidupnya.

Selain kondisi Kota Bogor yang menyebabkan para migran ini berpemikiran materialis, faktor kondisi migran juga berperan serta. Seringkali migran diposisikan sebagai tulang punggung kehidupan keluarga. Mereka bekerja bukan hanya untuk memenuhi kebutuhan hidupnya tetapi juga kehidupan keluarganya. Hal ini membuat migran secara tidak langsung berpikiran materialistis. Migran berusaha mencari uang sebanyak-banyaknya agar bisa dikirimkan buat keluarga di kampung.

\section{Perubahan Pola Pikir terhadap Sikap Individualisme}

Dalam adat istiadat suku Batak nilai-nilai kebersamaan sangat dijunjung tinggi dan selalu diajarkan kepada anak cucu. Seperti halnya tergambar dalam upacara-upacara yang ada di suku Batak. Sebagai contoh dalam upacara pernikahan, dimana seluruh kampung wajib untuk 
berpartisipasi membantu agar upacara pernikahan berjalan secara baik. Keikutsertaan mereka ini mengajarkan nilai kebersamaan dan saling tolong-menolong. Ketika saudara kesusahan maupun memperoleh kebahagiaan seluruh saudara merasakannya.

Setelah menjadi migran terjadi perubahan mengenai nilainilai kebersamaan. Intensitas migran di sektor informal untuk berkegiatan bersama dengan masyarakat berkurang. Berkegiatan dengan masyarakat dilakukan hanya pada saatsaat penting saja dan jika tidak penting mereka cenderung tidak ikut serta dalam masyarakat, hal ini disebabkan kondisi dan keadaan mereka yang sekarang sibuk mencari makan dan bekerja. Terutama kondisi pekerjaan mereka di sektor informal yang beraktivitas setiap harinya. Tidak ada hari libur bagi mereka. Perubahan pola pikir terhadap materi juga mempengaruhi sikap individualisnya orangorang Batak. Semakin orientasi hidup terhadap materi semakin individualis seseorang.

\section{TINGKAT KESEJAHTERAAN MIGRAN BATAK DI SEKTOR INFORMAL DI KOTA BOGOR}

Peneliti dengan menggunakan uji statistik T-test Paired atau uji beda yang berhubungan maka digunakan perangkat lunak SPSS dimana variable pengaruhnya adalah migrasi dan variabel terpengaruhnya adalah tingkat kesejahteraan. Kemudian melalui T-test Paired akan dilihat seberapa besar pengaruh migrasi terhadap tingkat kesejahteraan (sebelum dan sesudah migrasi) melalui nilai total yang didapatkan dari kuesioner mengenai tingkat kesejahteraan.

Hasil olah data statistik menunjukkan bahwa rata-rata (mean) tingkat kesejahteraan sebelum dan sesudah mengalami peningkatan dari 20,09 menjadi 31,00 dengan jumlah sampel $(\mathrm{N})=35$.

Berdasarkan aturan, jika sig $>0,05$ maka tidak ada hubungan antara sebelum dan sesudah migrasi dengan tingkat kesejahteraan migran Batak di sektor informal. Sebaliknya jika sig $<0,05$ maka ada hubungan antara sebelum dan sesudah migrasi dengan tingkat kesejahteraan migran Batak di sektor informal. Berdasarkan uji statistik didapatkan nilai sig 0,000 yang berarti adanya hubungan antara sebelum dan sesudah migrasi dengan tingkat kesejahteraan migran Batak di sektor informal. Sig 0,000 ini juga menandakan bahwa adanya perbedaan kondisi tingkat kesejahteraan sebelum dan sesudah migran pada taraf kepercayaan 95 persen.

Tabel 17. Paired Samples Statistics Tingkat Kesejahteraan

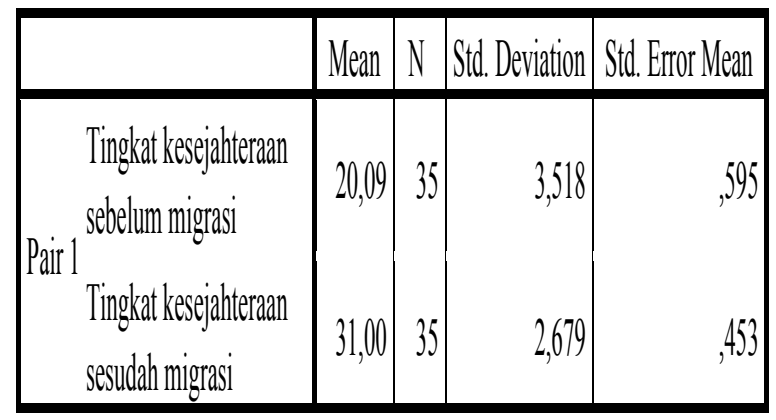

Tabel 18. Paired samples test tingkat kesejahteraan

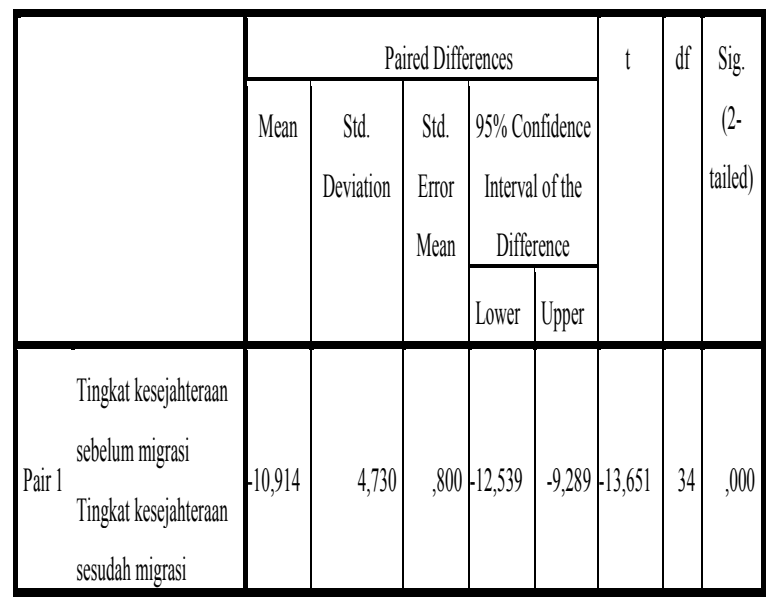

Perubahan tingkat kesejahteraan migran batak yang bekerja di sektor informal yang mau diteliti adalah tingkat pendapatan, akses terhadap layanan kesehatan dan kondisi perumahan serta kepemilikan barang berharga yang dimiliki oleh rumah tangga. Berikut akan diuraikan variabel perubahan tingkat kesejahteraan tersebut.

\section{Perubahan Tingkat Pendapatan}

Pendapatan migran Batak di Kota Bogor mengalami peningkatan. Pendapatan yang diperoleh migran di daerah asal cenderung stabil dan seringkali menurun, sedangkan kebutuhan hidup meningkat. Hal ini berdampak tidak terpenuhinya semua kebutuhan hidup migran. Penurunan pendapatan migran di daerah asal disebabkan sudah banyaknya orang yang melakukan pekerjaaan yang sama. Persaingan merupakan hal yang tidak bisa dihindari.

Selain itu seringkali jenis pekerjaan yang dilakukan sudah tidak mendukung lagi untuk dikerjakan. Pembangunan yang tidak terencana menjadi salah satu penyebabnya. Sebagai contoh jenis pekerjaan bertani dan berkebun yang dilakukan migran di daerah asal. Pembangunan seringkali berdampak kepada hilangnya lahan migran. Kehilangan lahan membuat produktivitas mereka menurun. Hal ini berdampak kepada penurunan pendapatan.

Di samping itu peran kebijakan pemerintah seringkali tidak mendukung para migran yang bertani dan berkebun. Pasar untuk hasil pertanian atau perkebunan tidak disediakan dengan baik dan benar. Harga bahan dasar untuk bertani dan berkebun juga cenderung meningkat dan tidak diikuti dengan peningkatan harga barang-barang hasil pertanian atau perkebunan Pendapatan migran Batak di sektor informal di Kota Bogor mengalami peningkatan. Peningkatan berlangsung secara bertahap dan pasti. Faktor kerja keras juga berperan dalam peningkatan pendapatan mereka. Migran Batak hanya tahu bekerja dan bekerja. Mereka melakukan pekerjaan dengan sangat serius dan telaten. Mereka menjiwai apa yang sedang mereka lakukan.

\section{Perubahan Akses terhadap Layanan Kesehatan}

Fasilitas kesehatan di daerah asal migran dan di Kota Bogor sudah tentu sangat jauh berbeda. Di kampung fasilitas kesehatan didominasi oleh puskesmas, seandainya 
ada rumah sakit jaraknya sangat jauh dari tempat tinggal mereka. Di Kota Bogor fasilitas kesehatan dapat dikatakan sudah lengkap dan baik. Dari rumah sakit sampai dokter praktek sudah ada. Perubahan fasilitas ini memudahkan migran untuk mendapatkan pelayanan yang baik.

Berbicara tentang akses tidak terlepas dari kemampuan untuk mengakses. Kemampuan mengakses ini dipengaruhi oleh kemampuan perekonomian migran. Di daerah asal kemampuan mengakses pelayanan kesehatan termewah hanya sampai pada puskesmas karena di rasakan murah bagi para migran.

Berbeda halnya dengan Kota Bogor, tempat pengobatan didominasi oleh rumah sakit dan dokter praktek. Migran Batak yang bekerja di sektor informal di Kota Bogor dari segi kehidupannya sudah membaik. Hal ini berpengaruh pada akses terhadap pelayanan kesehatan. Tempat paling sering bagi migran berobat di Kota Bogor adalah rumah sakit.

Kondisi fasilitas pelayanan kesehatan memiliki pengaruh terhadap perekonomian migran. Semakin bagus fasilitas pelayanan kesehatan maka semakin besar juga biaya yang dikeluarkan dan sebaliknya semakin sedikit biaya yang dikeluarkan maka semakin terbatasnya pelayanan kesehatan yang diterima.Umumnya migran Batak di Kota Bogor jarang mengakses pelayanan kesehatan dokter praktek, hal ini disebabkan karena biayanya mahal.

\section{Kondisi Perumahan serta Kepemilikan Barang Berharga}

Dalam penjelasan sebelumnya, disebutkan bahwa telah terjadi perubahan pendapatan migran Batak yang bekerja di sektor informal di Kota Bogor. Seiring dengan perubahan pendapatan tersebut, kehidupan migran Batak juga mengalami perubahan. Seperti yang telah dijelaskan dalam karakteristik migran, dikatakan bahwa kondisi tempat tinggal migran terdiri dari tiga tempat yaitu, menumpang dengan saudara, mengontrak dan memiliki rumah sendiri, sedangkan di daerah asal, kondisi perumahan tempat tinggal migran masih didominasi dengan ikut orang tua. Perubahan kondisi tempat tinggal secara bertahap dialami oleh migran.

Berbicara tentang kondisi perumahan tidak terlepas dari fasilitas perumahan yang dimilikinya. Dalam penelitian ini fasilitas perumahan yang dilihat diantaranya: jenis dinding, fasilitas kamar mandi, sistem penerangan, sumber air bersih, dan bahan bakar untuk memasak . Membandingkan fasilitas perumahan antara daerah asal dan daerah tujuan, perbedaan yang sangat jelas terlihat pada sumber air bersih dan bahan bakar untuk memasak. Di daerah asal sumber air bersih air sungai dan air sumur, sedangkan di kota 47,99\% penduduk menggunakan layanan air bersih dari perusahaan air minum milik daerah.

Dari segi bahan bakar, di daerah migran masih mengandalkan kayu bakar dan minyak tanah, sedangkan di Kota Bogor sudah menggunakan gas. Penggunaan kayu bakar dengan alasan ekonomi. Minyak tanah di daerah asal harganya mahal. Namun kebanyakan migran masih menggunakan minyak tanah dikarenakan minyak tanah dirasakan lebih aman daripada menggunakan gas.

Selain kondisi perumahan juga dilihat kepemilikan barang berharga yang dimiliki oleh migran. Jika dibanding dengan daerah asal kepemilikan migran akan barang berharga jelas jauh berbeda. Pendapatan yang seadanya di daerah membuat kemampuan migran untuk memiliki barangbarang berharga menjadi kecil.

Pendapatan yang meningkat di Kota Bogor membuat migran mampu untuk membeli barang-barang berharga. Kepemilikan barang berharga ini juga mendukung pekerjaan yang mereka lakukan seperti kepemilikan motor yang digunakan sebagai sarana transfortasi yang mendukung pekerjaan mereka

Selain kondisi kehidupan migran yang sudah membaik, umumnya diikuti dengan kondisi kehidupan keluarganya yang ikut membaik. Migran yang sudah sejahtera akan berusaha membantu kehidupan keluarganya di kampung.

\section{SIMPULAN DAN SARAN}

\section{Simpulan}

Berdasarkan hasil-hasil penelitian yang surah dijabarkan diatas maka dapat dibuat beberapa kesimpulan seperti di bawah ini:

1. Terjadi perubahan sosial yang signifikan pada individu migran Batak yang bekerja di sektor informal di Kota Bogor. Dari segi interaksi sosial, terjadi perubahan interaksi migran dengan orang-orang yang berbeda latar belakang suku, agama dan kelas ekonomi. Dari segi hubungan-hubungan kekeluargaan, terjadi perubahan kedekatan dan kebersamaan dengan keluarga ke arah yang tidak baik. Hal ini disebabkan karena intensitas bertemu dan berkomunikasi yang berkurang.

2. Tidak terjadi perubahan budaya yang signifikan pada individu migran Batak yang bekerja di sektor informal di Kota Bogor. Dari segi nilai-nilai agama, tidak terjadi perubahan karena nilai-nilai agama telah mengakar dan melembaga pada individu migran Batak. Dari segi nilai-nilai adat istiadat, terjadi perubahan yang disebabkan karena kondisi dan keadaan wilayah yang berbeda sehingga tidak memungkinkan nilai-nilai adat istiadat ini dilakukan. Namun demikian dari segi pola pikir ternyata mengalami perubahan yang sangat signifikan. Orientasi terhadap materi meningkat yang berdampak terhadap sikap individualis yang semakin tinggi. Hal ini bisa dilihat dari kebiasaan hitung-hitungan untung rugi yang biasa dilakukan sebelum melaksanakan sesuatu serta partisipasi dalam kehidupan bermasyarakat yang jarang dilakukan.

3. Terjadi peningkatan kesejahteraan pada individu migran Batak yang bekerja di sektor informal di Kota Bogor. Dari segi pendapatan ditandai dengan peningkatan pendapatan migran. Dari segi akses terhadap pelayanan kesehatan dapat dilihat dari akses migran mendapatkan pelayanan rumah sakit serta dokter praktek. Dari segi kondisi perumahan serta kepemilikan barang berharga dapat dilihat dari kondisi perumahan tempat tinggal migran yang semakin membaik serta kemampuan migran untuk memiliki barang berharga yang semakin tinggi.

\section{Saran}

Saran yang dapat diberikan sesuai dengan hasil penelitian yang didapatkan adalah: 
1. Besarnya interaksi yang dilakukan migran Batak yang bekerja di sektor informal di Kota Bogor dengan orang-orang yang beragam suku, agama dan lapisan ekonomi seharusnya diimbangi dengan interaksi yang terus dijaga rutin dengan sesama suku, sesama agama dan berbagai lapisan ekonomi yang ada. Hal ini dimaksudkan agar interaksi yang dilakukan dengan orang-orang yang beragam itu tidak membuat para migran melupakan asal usulnya.

2. Perubahan hubungan-hubungan kekeluargaan pada individu migran Batak yang bekerja di sektor informal di Kota Bogor dapat diminimalkan dengan terus menjaga komunikasi yang baik dengan keluarga.

3. Untuk menjaga nilai-nilai agama dan adat istiadat yang stabil, sangat dianjurkan agar para migran ini berpartisipasi aktif dalam berbagai organisasi-organisasi kedaerahan. Organisasi kedaerahan ini dapat didasarkan satu suku, marga, maupun agama. Hal ini dimaksudkan karena organisasi kedaerahan ini seringkali dapat berperan sebagai kontrol atas segala tindakan dan perilaku migran sehingga tetap stabil.

4. Perubahan pola pikir ke arah materialistis dan sikap individualis migran seharusnya dapat dikontrol dengan baik. Nilai-nilai agama dapat digunakan sebagai benteng pertahanan yang dapat mengurangi pola pikir ke arah materialistis dan sikap individualis. Selain itu komunikasi yang baik seharusnya juga dijalin migran Batak bukan hanya dengan sesama orang Batak tetapi juga dengan masyarakat sekitar tempat mereka tinggal sehingga hubungan mereka dengan masyarakat dapat terjalin secara harmonis

\section{DAFTAR PUSTAKA}

Amalia R. 2013. Struktur dan Strategi Nafkah Pedagang Makanan di Sektor Informal Daerah Suburban Kabupaten Bogor. [skripsi]. Bogor(ID): Departemen Sains Komunikasi dan Pengembangan Masyarakat. Fakultas Ekologi Manusia Institut Pertanian Bogor.

Badan Perencanaan Pembangunan Daerah Kota Bogor. [tidak ada tahun]. Kondisi Umum Kota Bogor. [Internet]. [diunduh tanggal 4 Mei 2014]. Dapat diunduh dari:http://bappeda.kotabogor.go.id/ index.php/downloaddokumen/category/5rpjmd-kota-bogor?download=50:bab-iikondisiumumkotabogor-rpjmd

Badan Pusat Statistik. 2000. Indikator Kesejahteraan Rumah Tangga. Jakarta (ID).

Hatu R. 2011. Perubahan Sosial Kultural Masyarakat Pedesaan. Jurnal Inovasi. [Internet]. [diunduh tanggal 23 Desember 2013]. 8(4):1-11. Dapat diunduh dari: http://ejurnal.ung.ac.id/index.php/ JIN/article/view/721/664

Halim J. 2002. Pengaruh Perubahan Sosial pada Sistem Kekerabatan Masyarakat Keturunan Cina di Tangerang Banten. [Tesis]. Semarang (ID): Universitas Diponegoro. 159 hal.

Koentjaraningrat. 1986. Kebudayaan, Mentalitas dan Pembangunan. Jakarta (ID): PT Gramedia
Kozok U. 1999. Warisan Leluhur Sastra Lama dan Aksara Batak. Jakarta (ID): Gramedia.

Lauer RH. 2001. Perspectives on Social Change. Perspektif tentang Perubahan sosial. Penerjemah Alimandan SU. Jakarta (ID): PT Rineka Cipta.

Marius JA. 2006. Perubahan Sosial. Jurnal Penyuluhan. [Internet]. [diunduhtanggal23 Desember2013].2(2): 125-132. Dapat diunduh dari: http://repository. ipb.ac.id/bitstream/handle/123456789/42870/ Jelamu.pdf

Martin P. 2003. Sustainable Labor Migration Policies in a Globalizing World. University of California.

Naim M. 1979. Merantau: Pola Migrasi Suku Minangkabau. Yogyakarta (ID): Gadjah Mada University Press.

Parassa HS. 2012. Peranan Pemerintah dalam Peningkatan Kesejahteraan Masyarakat Desa Wasuponda Kabupaten Luwu Timur. [skripsi]. Makassar (ID) Universitas Hasanuddin.

Pusat Studi Pembangunan Pertanian dan Pedesaan. 2010. Gambaran Umum Kota Bogor. [Internet]. [diunduh tanggal 4 Mei 2014]. Dapat diunduh dari: http:// psp3.ipb.ac.id/file/ikm-BAB\%203.pdf

Rusli S. 2012. Pengantar Ilmu Kependudukan. [edisi revisi]. Jakarta (ID): LP3ES

Safrida. 2008. Dampak Kebijakan Migrasi terhadap Pasar Kerja dan Perekonomian di Indonesia. [Disertasi]. Bogor (ID): Sekolah Pascasarjana Institut Pertanian Bogor.

Sahab K. 2002. Perubahan Nilai-Nilai Sosial Budaya Kajian Kasus Perubahan Fungsi Lahan Pertanian ke Non Pertanian pada Masyarakat Bengkulu. [Tesis]. Bogor (ID): Institut Pertanian Bogor. 109 hal.

Sayogyo. 1977. Garis Kemiskinan dan Kebutuhan Minimum Pangan. Indaryanti Y, editor. 22 Tahun Studi Pembangunan, Pembangunan Kemiskinan, Pembangunan Agribisnis dan Revitalisasi Pertanian. Bogor (ID): PSP3-LPPM IPB.

Sinaga MS. 2012. Migrasi dan Proses Interaksi Sosial Migran Batak: Studi Kasus Migran Parsadaan Pomparan Toga Sinaga Dohot Boru Cabang Bogor. [Skripsi]. Bogor (ID): Institut Pertanian Bogor. 91 hal.

Soekanto S. 1990. Sosiologi Suatu Pengantar. Jakarta (ID): PT Raja Grafindo Persada.

Soemardjan S. 1981. Perubahan Sosial di Yogyakarta. Yogyakarta (ID). Gajahmada University Press.

Sumodiningrat, Gunawan, Mudrajad. 1990. Strategi Pembangunan Pertanian dan Industri: Mencari Pola Simbiosis. PRISMA. LP3ES. Jakarta.

[UU] Undang-Undang Republik Indonesia Nomor 11 Tahun 2009 tentang kesejahteraan. 